\title{
JHCY
}

JOURNAL OF THE HISTORY OF

Childhood AND Youth 


\section{IMMIGRANTS, ALIENS, EVACUEES: EXPLORING THE HISTORY OF IRISH CHILDREN IN BRITAIN DURING THE SECOND WORLD WAR}

\section{INTRODUCTION}

The Irish in Britain during the Second World War occupied an anomalous and much misunderstood position, being in Bronwen Walter's apposite analysis, "outsiders inside," a large minority of nationals of a neutral country residing in a belligerent one. Simultaneously invisible, due to their whiteness and cultural similarities, and hyper-visible as aliens of a neutral country, they were strictly regulated with new forms of identification and police checks. Along with citizens of enemy countries such as Germans and Italians, the Irish "also attracted hostility and suspicion as Fifth Columnists and spies." The Irish community was not, in fact, demonstrably disloyal to the Allies, but instances such as those reported by Cardinal Hinsley of Westminster to Archbishop Downey of Liverpool of priests and nuns carrying letters from Britain to Ireland to avoid censorship would have stoked fears if they had become public. ${ }^{1}$

While major narratives of the Irish in Britain have recognized adult experiences in the war, children have remained liminal or absent. This can be explained by limited sources, but it also suggests a collective cultural amnesia regarding Irish people's role in a war that was not their "people's war." This placed them outside the "imagined community" response to the war by adults and children alike. In Cadogan and Craig's analysis of the Second World War "in children, especially, patriotism was intense and uncomplicated, and from the beginning girls as well as boys were enthusiastic in their efforts to participate." Did Irish children similarly engage in such efforts? ${ }^{2}$

Elsewhere I have argued for the concept of "historical myopia" in excluding the contributions of Irish women to the British home front effort; here I wish to shine a light on the experiences of children as viewed from the same source

Journal of the History of Childhood and Youth (v9.2) (c) 2016 by Johns Hopkins University Press 


\section{IMMIGRANTS, ALIENS, EVACUEES}

material, Irish travel permit applications made in Britain during the Second World War. Such applications, made by adults on behalf of children under sixteen years, reveal the concerns, journeys, and profile of Irish children, many of whom were being evacuated, and some of whom had experienced evacuation within Britain before exiting to Ireland.

\section{IRELAND, EMIGRATION, AND THE SECOND WORLD WAR}

There were well-trodden migration paths to Britain by the Second World War of both seasonal and more permanent varieties. Groups laboring on the farms of Scotland and northern England included children. The 1937 investigation into seasonal migration found children were predominant in groups originating from Achill Island, County Mayo, and Donegal that went to "Ayrshire in June for the early potato lifting and thence to other districts for the later crop, returning to Ireland about the beginning of November." They worked with just a few men under the direction of a male "gaffer," the rest of the group being women. ${ }^{3}$

A dramatic shift occurred during the war as migrants were actively recruited for the British home front and forces. Scholarship over recent decades has concluded that Ireland's neutrality was a compromised one, with the sharing of intelligence, resources, and, crucially, workers-all elements that violated accepted definitions of strict nonalignment. The previously held assumption of Ireland's "Plato's Cave" status as asserted by Lyons-that Ireland, isolated from the exigencies and impacts of war, emerged in the aftermath blinking in disbelief-has been widely discredited. Many historians have detailed involvement between the two governments and contributions of volunteer soldiers and female auxiliaries, all of which demonstrate an interconnected, politically sensitive policy understood as a pro-Allied form of benevolent neutrality. This has undermined nationalist definitions of Ireland as defining its independence by neutrality, and it stands in contrast also to understandings of the war as being a "high water mark of Britishness" if significant minorities of its civilian and soldiering populations were not, in fact, British. War was a hard-hitting reality for thousands of Irish emigrants, including children. ${ }^{4}$

This essay explores two core narratives: wartime immigrant children and the tangled relationship between Ireland and Britain that shaped their experiences. While the source material used does not emanate from children themselves, it does, however, shine a light on them, and I attempt to explore their perspective as much as possible. This is a different, but fundamentally important lens with which to view this history. As Mintz has argued: "childhood ... is the true missing link: connecting the personal and the public ... the domestic and the state." ${ }^{5}$ 


\section{EVACUATION}

The official evacuation scheme began on September 1, 1939, and moved 1,473,000 children and adults from the cities of Britain to the reception areas before war was declared on September 3, 1939. A second wave of evacuations from London in September 1940 saw 1,250,000 adults and children moved, and a further evacuation from this city occurred in July 1944 . The extant permit applications are dated, in the main, from 1940 to 1942, thus covering the major periods of evacuation. This mass movement was regarded as momentous and provoked vast photographic archives, although the differences between the children-based on ethnic, religious, or citizenship status-are not evident in the photographic corpus of material. This is despite reminiscence work from the 1960s that records, for example, the experiences of Chinese evacuees and their hostile reception from local children. ${ }^{6}$ Clearly the Irish (born or ethnically identified) were not the only foreign nationals within the evacuation program, but the wider cultural memory of the evacuation program does not reflect such heterogeneity.

John Welshman has evoked the myriad problems encountered by evacuees, including a hostile reception from locals, exaggerated reports of lice and skin diseases, and derogatory depictions of their manners and hygiene. There was also the strangeness of the countryside to deal with. The evidence is scarce on the specific evacuation of Irish children, although the travel permit files reveal evacuation within Britain prior to journeys to Ireland. Mrs. C., a twenty-eightyear-old mother of one, was evacuated with her baby from London to Scotland before applying to return to her native Roscommon for the "safety of the baby." Another applicant, Mrs. B., a thirty-eight-year-old housewife, stated she was evacuated from Liverpool to Wigan in her application to visit her three evacuated children in Louth. ${ }^{7}$ Despite frequent references in contemporary newspapers (indicating this was not a secretive process), evacuation stories in Ireland are rare and largely forgotten in the literature on the "Emergency."

Tuttle has argued for contrasting paradigms of the family in the 1930s and 1940s: whereas the Great Depression had "centripetal momentum," pulling families together for survival, the war had a "centrifugal momentum," which forced families to rearrange roles, often pulling them apart. Emigration and evacuation were forces that may have taken immigrant children away from their wider networks of family and community who would have helped to normalize or ease the fear of air raids. Tracing this history from the child's perspective poses challenges in terms of an evidence base. As Maynes has highlighted: "children cannot and do not speak for themselves in most historical records about them." ${ }^{\prime 8}$ This is the case with the evidence this essay draws on: analysis of 


\section{IMMIGRANTS, ALIENS, EVACUEES}

over 23,000 travel permit applications from Irish people in Britain, specifically, the 2,600 applications that were made on behalf of 4,378 children: 2,168 boys, 2,137 girls, and seventy-six children whose gender wasn't stated. ${ }^{9}$

The evacuation of children internationally had parallels to the Irish experience. An official scheme for evacuating children was coordinated by the Children's Overseas Reception Board (CORB), and 2,664 children were evacuated from Britain in 1940 to Canada, Australia, New Zealand, and South Africa, although approximately 14,000 children had been evacuated via private schemes as war loomed. This is in addition to the mothers, children, and persons with disabilities evacuated in the six months before the war. Given the absence of travel regulations between Britain and Ireland, it is impossible to know how many Irish children were similarly evacuated in the months preceding the conflict, but they were among the 4,078,000 people who had evacuated by September $1944 .^{10}$

\section{GLIMPSES OF IRISH EXPERIENCES OF WAR IN BRITAIN}

The propensity of Irish migrants to settle in major urban centers in Britain ensured they were in the direct firing line when aerial attacks occurred. Indeed, the highest proportion of applicants (27 percent) were living in London, and thus experiencing the full effects of the Blitz (1940-41). Irish children suffered the same horrors of bombing, rationing, and deprivations that characterized the war, yet their experiences of war or evacuation are available often as mere glimpses in the historical record. For example, they are noted as among the range of nationalities included in the Cambridge Evacuation Survey, a socio-psychological study of London evacuees that focused in particular on the perspectives of children, although nationality is not a major feature of the analysis. A case study of records from the Liverpool Catholic Diocesan Archives is offered here in an attempt to complement the evidence provided by permit applications. Liverpool, being a port city, has historically been populated by Irish, and thus records from the Catholic repository often reflect on the Irish community, although some creative license is also taken in order to examine this issue as it is not always known if Catholics referred to are Irish, or of Irish heritage. A letter, for example, signed "Gerard and Paul" (the former a popular Irish name) provides an important insight. The two brothers, staying in Eardisland, reported to their parents "we have no Church to go to." As the Catholic church was too far away, their foster family took them to Church of England services. In an identical case, the parents complained to the Department of Education, and it was also raised within the Catholic Church hierarchy. Indeed, Archbishop Downey of Liverpool personally urged the British minister for health, Ernest Brown, to take seriously the need to place Catholic children from Liverpool in homes of similar faith. ${ }^{11}$ 
Concern over the religious duties of Catholics evacuated from Liverpool was expressed from the beginning. In 1939, the Catholic Action Office in Liverpool initiated a scheme to circulate Catholic magazines and pamphlets to evacuees. Throughout the war, parents in Liverpool were urged by the Catholic Church and the Catholic Teachers' Federation to ensure their children went to Catholic families, or that their children did not attend non-Catholic services or schools. ${ }^{12}$ While this may have been a real concern shared by parents, it seems curious that it emerged in the context of dangers from air raids: potential dangers to the soul were ranked equally important with physical dangers. In addition, there was a practical problem of who should look after children when foster parents attended their own religious services. In many cases, the Catholic teacher evacuated with the children looked after them, but continual problems arose due to different faiths within the Protestant fold having services at different times.

By 1944, bombings of Liverpool had ceased, and the city became a receiving center for London evacuees. A July 1944 memo from the Archbishop of Westminster reveals concern that as the official scheme did not record children's faith, they should have "some external though unobtrusive indication of their religion" with the suggestion that parents or teachers write "the word 'Catholic' or 'R.C.' on the label which the child wears." There was a further request that Catholic parish priests be allowed to scan lists of offered billets to identify Catholic homes, a request complied with by the Public Assistance Committee, coordinators of the scheme. ${ }^{13}$ Irish children were literally labeled with difference if they were Catholic, which the majority were.

It is interesting to speculate whether experiences of evacuation within Britain may have been different for Irish children: many were born in or regularly visited the rural areas that their parents came from; they may have traveled once or twice a year on trains and ships; they may even have had the experience of being away from their parents for long periods if they lived in households where either parent engaged in seasonal migration or if they were brought to Ireland for summer holidays. Would they have shared the sense of strangeness at the new "British scenes and soundscapes" of their evacuation destinations? Or would their interstitial identities, or the "curious hybridities" in Gray's analysis, of their existence as Irish in Britain have helped them negotiate another new space? ${ }^{14}$

\section{IRISH EVACUATION}

Irish children were evacuated from Britain either through the personal arrangements of their parents or through the official scheme, negotiated with the southern Irish government. Reports of evacuees from Britain appeared in Irish 


\section{IMMIGRANTS, ALIENS, EVACUEES}

newspapers in the autumn of 1940, with the Irish Red Cross supplying assistance for hundreds entering through Dún Laoghaire, County Dublin, and Cork, providing them with hot drinks, help with children, food, and transport before an official scheme emerged. ${ }^{15}$

The scheme was announced on December 19, 1940, by Malcolm Macdonald, British minister for health, who had tried to persuade Ireland to enter the war with the promise of ending partition. Although Éire did not enter the war, negotiations for the evacuation of women and children were successful, and within one month 465 mothers and 1,263 children had registered with their local authorities in Britain. One-third (153) were mothers in London, with the rest scattered throughout the country. Mothers (who did not have to be Irish citizens) resident in evacuation areas wishing to go to Ireland needed to make their own arrangements for travel and lodgings (to be approved by the Irish government) and had to agree to remain in Ireland for the duration of the war. In return, they were given free travel vouchers and a lodging allowance of five shillings per week per mother and for children over fourteen years, with three shillings allowed for younger children. Thus the British government was paying for Irish people and their children, who may have been born in Britain, to evacuate and to maintain them while they stayed in Ireland, often with family members. Unlike in Britain, children had to be accompanied due to considerations for "the responsibilities involved in conveying the children and in caring for them when they would be out of reach of their parents." 16 This stance on sending children to Ireland reveals a sharp difference to the scheme within Britain or the CORB program, and it seems caution was employed by the British authorities. In March 1941, the scheme was widened to applicants in any part of Britain who had been made homeless by bombing.

Advertisements seeking or offering evacuee accommodation appeared in the Irish Times throughout the war. These reveal the extra-familial responses to evacuees who presented economic opportunities, such as this one from February 1941: "Accommodation for Evacuees from lady living in safe area, County Wicklow, 30 miles from Dublin, beside bus, rail, shops, post office, churches; house large, comfortable, large grounds, own produce." The desperation of parents to get their children to safety is conveyed in others: "Wanted: Teacher, Nurse or School [to] take Girl, 9 years, safe area: urgent."17

Although mothers were not required to obtain travel or exit permits according to the official announcement, applications recording evacuation can be found in the records, including some from English nationals refused permits because they needed to travel on British ones. This suggests second or subsequent generations of Irish in Britain utilized family networks to get their 
children to safety, as well as women married to Irish citizens, who were allowed to participate in the scheme. Children ranged from one week up to the age limit of fifteen years. The large nature of Irish families is attested to with some families bringing seven children, but the average number of children traveling was 3.3. ${ }^{18}$

Intending passengers needed to state why they were traveling, and thus many persons evacuating children, or visiting children previously evacuated, are revealed (table 1). ${ }^{19}$ Out of a total of 23,481 applications analyzed, 23,040 had explanations. ${ }^{20}$ Of this, a total of 1,169 were reasons directly war related. Many were visiting children left in Ireland or evacuated there or were returning to collect children previously evacuated. Mr. T. from Sligo, working in the building trade, applied from Bolton, Lancashire, in June 1941, for a permit as he was "going to take my baby home from my parents," an indication that being separated from children did not suit everyone, and as table 1 shows, a total of 43 applicants were doing the same.

The key message from the above data is this: Irish people were using the vocabulary of war to explain their reasons for return. In their own words, they were articulating their journeys in the broader context of the conflict, and given that they were not restricted in this section of the form in how they expressed

Table 1: Reasons for Journey Relating to War, by Gender (N=1169)

\begin{tabular}{|c|c|c|c|c|c|}
\hline $\begin{array}{l}\text { Reason for Travel from } \\
\text { Britain to Ireland }\end{array}$ & $\begin{array}{l}\text { Number } \\
\text { of Men }\end{array}$ & $\begin{array}{l}\% \text { of Total } \\
\text { for this } \\
\text { reason }\end{array}$ & $\begin{array}{c}\text { Number of } \\
\text { Women }\end{array}$ & $\begin{array}{l}\% \text { of Total } \\
\text { for this } \\
\text { reason }\end{array}$ & $\begin{array}{c}\text { Total } \\
(100 \%)\end{array}$ \\
\hline $\begin{array}{l}\text { Evacuation of children but } \\
\text { returning to UK themselves }\end{array}$ & 22 & $37 \%$ & 37 & $63 \%$ & 59 \\
\hline Evacuation of self & 9 & $18 \%$ & 42 & $82 \%$ & 51 \\
\hline $\begin{array}{l}\text { Evacuation of self and } \\
\text { children }\end{array}$ & 42 & $10 \%$ & 383 & $90 \%$ & 425 \\
\hline $\begin{array}{l}\text { To bring family back over } \\
\text { to Britain }\end{array}$ & 25 & $58 \%$ & 18 & $42 \%$ & 43 \\
\hline $\begin{array}{l}\text { To visit or return to } \\
\text { child(ren) stated as } \\
\text { previously evacuated }\end{array}$ & 195 & $64 \%$ & 110 & $36 \%$ & 305 \\
\hline $\begin{array}{l}\text { To return to child(ren) } \\
\text { unspecified if evacuated or } \\
\text { were always in Ireland }\end{array}$ & 122 & $43 \%$ & 160 & $57 \%$ & 282 \\
\hline $\begin{array}{l}\text { Returning because of } \\
\text { bombing of home in Britain }\end{array}$ & 1 & $25 \%$ & 3 & $75 \%$ & 4 \\
\hline Total & 416 & & 753 & & 1169 \\
\hline
\end{tabular}




\section{IMMIGRANTS, ALIENS, EVACUEES}

their reasons for return, they wished to convey the seriousness of their purpose. These were not holidays; they were flights from bombs, visits to evacuated children, or journeys to ensure their safety. Table 1 demonstrates a complex nexus of care being provided for Irish children. As might be expected given gendered care roles, women were more likely than men to be evacuating with their children (383 female applicants versus forty-two male). Although this information is partial, it is likely such trends continued, with the pattern of men returning temporarily to Ireland to visit wives and children when conditions allowed and pregnant women and children returning to avoid the war. This evidence is unique in affording insights into Irish people's reactions to the war and their negotiation of childcare arrangements.

Furthermore, 625 women (2.7 percent) claimed to be traveling solely because they were pregnant, a time of worry for many women but especially so in the context of war. A case history exemplifies the challenges for pregnant women. Mrs. H., from a small town in Kildare and married to a British man, detailed her reason for leaving Rye in Sussex as "leaving evacuated town for refuge and forthcoming confinement at home." A housewife, she detailed the children she already had: a girl aged three years and eight months, a boy aged two years and eight months, and male twins aged one year and one month. Mrs. H. and her family had been experiencing significant enemy action. On August 12, 1940, six weeks before her application, the station for detecting low-flying aircraft had been hit by a German plane led by Hauptmann Walter Rubensdörffer. Further attacks came on August 15 with German bomber planes cutting electricity in Rye and Dover. The uncertainty and fear generated by such attacks undoubtedly played a part in Mrs. H.'s return to her native town with her four children. Indeed, details are revealed of nervous strain, tension, and fear in personal statements explaining the applicants' desire to return, including statements about children. Mary from Dublin, also living in Middlesex with her seven-year-old daughter, stated the child was suffering from nerves due to the war; another Mary, also from Dublin, a housewife in Surrey, stated: "Air raids in the district causing trouble to the children," referring to her two boys and a girl, ages three, four, and eight years. Health and nervous issues were shared by mothers and children alike. Mrs. M., a thirty-four-year-old housewife from Dublin and mother of three, stated her reason for leaving Liverpool as "to take the children to their Grandma's and aunties for safety and to restore my own health as my nerves have gone[,] up night and day on my own with them."21

Sometimes evacuation itself caused nervous issues for children: Mrs. C. from Roscommon, a fifty-one-year-old housewife living in Manchester, stated she wished "to see my child that is fretting," explaining in a letter that she 
evacuated her son at the beginning of the war to her parents and was worried. However Mrs. C. only intended to visit for Christmas, indicating this would be enough to settle the child. Children do not always seem to have been left with relatives, and one can only imagine the distress that institutionalization caused. Mrs. O'C. from Westmeath, a thirty-two-year-old munitions worker based in London, reported her journey in June 1941 as being "to see my children in Eire who is refugees there [sic]." She was traveling to the Convent of Mercy in Rushbrooke, Cobh, Cork, indicating she lodged the children there while working in Britain. The evacuations or separations of Irish children from their parents also led to long gaps between visits, in common with many evacuated children within Britain. Mrs. S., a British-born woman with parents in Cork (suggesting a pattern of familial migration), reported her journey from London in March 1941 as "to visit my evacuated children and mother having not seen them for 18 months."22 Having not been domiciled in Ireland at the founding of the state in December 1922, her application was refunded pending proving her citizenship status, thus further delaying her visit.

One of the crucial differences of being evacuated within Britain as opposed to Ireland was that the British authorities guaranteed food, board, and access to provisions such as winter clothes and boots for the most needy in certain areas. The scheme for evacuating women and children was undertaken on the condition that the women would not become a liability to the state. This, however, was either not understood by some women, or else was regarded as a flexible rule.

The case of Mrs. F. in Mayo is illustrative. ${ }^{23}$ On arriving in Ireland in 1941, she applied for home assistance on reaching her father-in-law's house in Mayo. She had been receiving assistance in Liverpool, her husband being unable to work due to poor health. Mrs. F. claimed she was told she would get comparable assistance in Ireland. Mrs. F.'s children ranged from two to fourteen years, and documentation reveals something of their lives: having lived on public assistance in what was likely to have been crowded conditions in Britain, they were now in a safe area, but again impoverished. On receiving the application from the Mayo Board of Health and Public Assistance, the secretary of the Department of Local Government and Public Health replied curtly, refuting Mrs. F.'s claims (which were approved of by the Mayo Board) by restating the rules regarding self-support, clarifying that assistance was only meant to be given if mothers became destitute after arrival in Ireland. Therefore, Mrs. F. did not qualify. Furthermore, they wanted it investigated by the British Ministry of Health who wrongly informed her. The investigation found Mrs. F. had been mistakenly advised, and the British Ministry of Health undertook to cover the cost of her assistance. 


\section{IMMIGRANTS, ALIENS, EVACUEES}

This, and other correspondence, reveals a certain incongruity in the relationship between Britain and Ireland. The British government undertook the administrative and financial responsibility of delivering citizens of a neutral country to their homeland and maintaining them while there. Analyzing the records on evacuated Irish citizens reveals many of them needed short- or longterm financial assistance. Seventeen cases of requested assistance between 1941 and 1944 were found, often for women coming from the major cities of Britain to their native counties, applying on their own behalf and for their children. Periods of assistance ranged from one week to six months (and possibly longer as records are incomplete). Clearly the burden of care for Irish people did not fall on the Irish government exclusively; it attempted to get private individuals and the British government to take financial responsibility. The prime reason for evacuation - the safety of children-does not appear to have been the main priority for the Irish government, but rather the cost.

The Irish government seems to have had health as well as financial concerns regarding these evacuated children, in what can only be seen as a fear of contamination. The Department of Health urged that the local medical superintendent officer of health should be informed of arrangements

so that he may be in a position to arrange where necessary for a family being kept under observation for a period and to take any other measures which he may deem desirable in the interests of public health. ${ }^{24}$

This observation, while perhaps practical from the point of view of the health management system, is not particularly sensitive.

A rare insight into Irish children's experiences of evacuation within Britain comes in Ronnie Carroll's memoir, Luck of the Irish. In this account, Carroll records how he and three siblings experienced multiple evacuations throughout the war, a disruption keenly felt as they had arrived from Ireland just prior to the conflict. Carroll's sister, Mary, experienced sexual abuse in their first billet in Norwich, and the family was subsequently rehoused for a short time in Cornwall, before returning to London and experiencing air raids. Finally, the family was divided, with the two girls being evacuated to an Essex convent and the two boys to a private house, with subsequent relocations for them to various boarding schools. In Carroll's account, the evacuation arrangements were inadequately assessed, and while they had been well looked after in Cornwall, the family suffered from abusive and unscrupulous treatment in some placements. In his own words "living with someone in loco parentis, euphemistically called our 'foster mother' with whom you had no relationship whatsoever, no bonds of love or affection . . . leaves you . . completely destitute of any bearings." 25 
Carroll's bitter indictment of the consequences of evacuation on his family (alcoholism and psychological damage) do not account for his difficult family circumstances, but his testimony speaks to the isolation, confusion, and panic that must have been felt by other children.

\section{CONCLUSION}

Irish immigrant children in Britain benefitted from the networks of kith and kin in Ireland and avoided some of the tragic effects of belligerency on children. Their history is hidden, and their stories have yet to be told, although fictional accounts such as Joan O'Neill's Daisy Chain War reveal a latent awareness. Permit applications confirm that not only were Irish people evacuating their children due to their own desires, they were participating in the official scheme. Indeed, one evacuee of Irish ethnicity, Pauline Donovan, was described as the "best loved evacuee in Britain" in the Irish Independent. ${ }^{26}$

The Irish, akin to the Italians in Ugolini's analysis, have been placed in a figurative "no-man's land" when it comes to commemoration in Britain ${ }^{27}$ and have not been featured in Irish historiography of the period thus far. Unlike the children of the kindertransport, these were not refugees fleeing from the oppression of an aggressor; they were Commonwealth citizens being assisted home or to relatives within Ireland. The relatively mundane nature of this evacuation may explain this lack of attention.

Welshman, in his sensitive exploration of the experience of evacuation, asks some questions which are pertinent to Irish children:

What was it like to be sent away? Did evacuation permanently alter relationships with brothers and sisters, and between children and parents? How did children feel when they finally returned home? And what was the significance of love and separation for the children's subsequent lives? ${ }^{28}$

These can apply to Irish cases but may have very different answers considering that migration was common in Irish families. Further questions to be added to Welshman's list might be: was a child's nationality taken into consideration and did it make any difference to the experience of evacuation? Does nationality play any part in why they are forgotten in the collective memory that exists in Britain about the war?

Ireland, an independent country with a new constitution asserting its sovereignty, was publicly and staunchly neutral, yet it received assistance and significant funding to bring back its own citizens; indeed it appears the Irish state did very little in this process. It could have paid for or provided vessels or transport within Ireland, contributed towards billeting allowances or issued 


\section{IMMIGRANTS, ALIENS, EVACUEES}

families with necessary provisions. It did none of this, the greatest assistance appearing to come from the Red Cross. These stories are important because the "people's war" was also a children's war, and Irish children were undeniably a part of it, if a forgotten part of it so far.

\section{NOTES}

The primary research from which this paper is drawn was completed during an Irish Research Council for the Humanities and Social Sciences (now the Irish Research Council) Postdoctoral Fellowship (2009-2011). My thanks to the Council for their support and also to the Royal Irish Academy, whose award of a Research Travel Mobility Grant (2011) assisted with research.

1. Wendy Webster, "Enemies, Allies and Transnational Histories: Germans, Irish, and Italians in Second World War Britain," Twentieth Century British History 25, no. 1 (2014): 63-86; Letter from Cardinal Hinsley to Archbishop Downey, August 12, 1941, Archbishop Downey Collection III, Series 2, War Papers, B/67, Liverpool Diocesan Archives; Enda Delaney, Demography, State and Society: Irish Migration to Britain 1921-1971 (Liverpool: Liverpool University Press, 2000).

2. Webster, "Enemies, Allies," 63; for accounts of the Irish in twentieth-century Britain, including the Second World War, see Jennifer Redmond, "The Largest Remaining Reserve of Manpower: Historical Myopia, Irish Women Workers and World War Two," Saothar 36 (2011): 61-70. Travel permits were introduced as a form of identification for journeys between Britain and Ireland and Britain and its islands. They were issued by the Irish high commissioner in Britain for journeys by Irish citizens to Ireland, lasted for multiple trips, and had to be accompanied by an exit permit from British authorities. The extant applications are part of the National Archives of Ireland Department of Foreign Affairs collection and are an incomplete cache of the applications made during the war. The author was given special permission to consult these files; Benedict Anderson, Imagined Communities: Reflections on the Origin and Spread of Nationalism (New York: Verso, 2006 revised edition); Mary Cadogan and Patricia Craig, Women and Children First: The Fiction of Two World Wars (London: Victor Gollancz Ltd., 1978), 213.

3. Report of the Inter-Departmental Committee on Seasonal Migration to Great Britain, 1937-1938 (Dublin: Stationery Office, 1938), Paragraph 19, Page 12, National Library of Ireland Reference R65/1.

4. F. S. L. Lyons, Ireland Since the Famine (London: Fontana, 1971). For more recent analyses of Ireland's neutrality see Brian Girvin and Geoffrey Roberts, eds., Ireland and the Second World War: Politics, Society and Remembrance (Dublin: Four Courts Press, 2000); Bryce Evans, Ireland During the Second World War: Farewell to Plato's Cave (Manchester: Manchester University Press, 2014); Clair Wills, That Neutral Island: A History of Ireland During the Second World War (London: Faber and Faber, 2007); Mary Muldowney, The Second World War and Irish Women: An Oral History (Dublin: Irish Academic Press, 2007); Bernard Kelly, Returning Home: Irish Ex-Servicemen after the Second World War (Dublin: Merrion Press, 2012); Stephen O'Connor, Irish Officers in the British Forces, 1922-45 (Houndmills: Palgrave, 2014); Michael Kennedy, "Neutrality: The Very Essence of Irish Independence?" History Ireland 21, no. 5 (2013): 10-11; and Ian S. Wood, Britain, Ireland and the Second World War (Edinburgh: Edinburgh University Press, 2010); Wendy Ugolini and Juliette Pattinson, "Negotiating Identities in Multinational 
Britain during the Second World War," in Fighting for Britain? Negotiating Identities in Britain during the Second World War, eds. Wendy Ugolini and Juliette Pattinson (Bern: Peter Lang, 2015), 1-24.

5. Steven Mintz, "Why the History of Childhood Matters," Journal of the History of Childhood and Youth 5, no. 1 (2012): 15.

6. John Welshman, Churchill's Children: The Evacuee Experience in Wartime Britain (Oxford: Oxford University Press, 2010), 5-6; Sara Fieldston, review of The Forgotten Generation: American Children and World War II, by Lisa Ossian, and The Lost Children: Reconstructing Europe's Families after World War II, by Tara Zahra, Journal of the History of Childhood and Youth 5, no. 1 (2012): 169; experiences of Chinese children as detailed in The Evacuees, cited by Cadogan and Craig, Women and Children First, 214.

7. File 15703, Travel Permit Collection, DFA, National Archives of Ireland. File number 39998, Travel Permit Collection. In Ireland the war was termed "the Emergency."

8. William M. Tuttle, Jr., "America's Home Front Children in World War II," in Children in Time and Place: Developmental and Historical Insights, eds. Glen H. Elder, Jr., John Modell, and Ross D. Parke (Cambridge: Cambridge University Press, 1993), 31, 38; Mary Jo Maynes, "Age as a Category of Historical Analysis: History, Agency and Narratives of Childhood," Journal of the History of Childhood and Youth 1, no. 1 (2008): 117.

9. The extant records are an incomplete cohort, the rest having been destroyed in a flood at the London Embassy in the 1950s (my thanks to Dr. Michael Kennedy, Royal Irish Academy, for this information). Not all applications were successful due to the requirements for domicile and citizenship registration imposed by the 1935 Irish Nationality and Citizenship Act. The rules surrounding the permit system changed according to the exigencies of war and were frequently misunderstood by the applicants.

10. The CORB dealt with applications for settlement from British children and those resettled in Britain from occupied Europe, North Africa, and Asia and operated until 1944. For more on the CORB see http://webarchive.nationalarchives.gov.uk/+/http://yourarchives.nationalarchives.gov.uk/index.php?title=Children\%27s_Overseas_Reception_Board, accessed November 16, 2015. The evacuation of citizens from London and other areas is detailed in Malcolm J. Proudfoot, European Refugees 1939-52: A Study in Forced Population Movement (London: Faber and Faber, 1957), 53.

11. Georgina Bathurst, Sibyl Clement Brown, John Bowlby et al., The Cambridge Evacuation Survey: A Wartime Study in Social Welfare and Education, ed. Susan Isaacs (London: Methuen \& Co., 1941); Undated letters in Archbishop Downey Collection III, Series 2, War Papers, C/2, Evacuation Correspondence, Evacuation 1941-Complaints, and C/32 Evacuation General Correspondence: Ministry of Health, Liverpool Diocesan Archives.

12. Pamphlet circulated to parish priests, November 10, 1939, Archbishop Downey Collection III, Series 2, War Papers, C/11, Evacuation Correspondence General: On Evacuation Problem 1939-1941; files contained in Archbishop Downey Collection III, Series 2, War Papers, C/17, Evacuation 1941, Timetables, Circulars, etc.

13. Letter from Archbishop of Westminster to unidentified priest, July 25, 1944, Archbishop Downey Collection Series III, Series 2, War Papers, C/33, Evacuation General Correspondence on Evacuation of London Children; Letter from Monsignor Adamson, Private Secretary to Archbishop of Liverpool, July 25, 1944, and response from G. W. Molyneux, Public Assistance Officer, August 29, 1944; all Archbishop Downey Collection 


\section{IMMIGRANTS, ALIENS, EVACUEES}

Series III, Series 2, War Papers, C/33, Evacuation General Correspondence on Evacuation of London Children.

14. Wendy Webster, "Transnational Communities of Allies," in Fighting for Britain? Negotiating Identities in Britain During the Second World War, Wendy Ugolini and Juliette Pattinson, eds. (Oxford: Peter Lang, 2015), 209; Breda Gray, "Curious Hybridities," Irish Studies Review 14, no. 2 (2006): 207-23.

15. "Evacuees Tell of Fatalities," Irish Independent, October 5, 1940, 7, and "Voluntary Aid for Evacuees: Red Cross Tribute," Irish Independent, December 17, 1940, 7.

16. “London Letter: The Parliamentary Debate," Irish Times, January 20, 1941, 4. A delegation from Ireland had been sent in late 1940 to work out the terms of the scheme, which included John Duff of the Department of Justice, H. A. Maynard of Posts and Telegraphs, and J. A. Scannell of the Ministry of Finance (as detailed in the Irish Times, November 9, 1940); quote from Minister Ernest Brown, Irish Times, May 16, 1941, 5.

17. "Evacuation: Accommodation Required and Offered" advertising column; April 22, 1941, 8; Advertisements, Irish Times, February 14, 1941, 1.

18. An example is File 22357, a thirty-nine-year-old woman from Mayo who gave the reason of taking her seven children, ranging from one to fifteen years old, to safety for her departure from Britain. They also recorded date and place of birth, their place of residence and destination, their occupation, their height, eyes, and facial features in addition to the details of the children they were bringing. Married women recorded the nationality of their husbands.

19. Four hundred forty-one had missing data-in most cases due to the use of a different form that did not ask this question. A total of forty descriptive categories were created to account for the different reasons for return visits home, ranging from visiting sick relations to recruiting workers.

20. Patrick Bishop, Battle of Britain: A Day-by-Day Chronicle (London: Quereus, 2009), 163, 185; File 16685, Travel Permit Collection; File 15652, Travel Permit Collection; File 16685, Travel Permit Collection; File 12915, Travel Permit Collection; File 16960; File 30735.

21. Mrs. H., File 14146; File 27730, Travel Permit Collection. No follow up details are available as to whether she pursued another travel permit.

22. All information taken from Department of Health A 121/0 "Evacuees on Home Assistance" File, National Archives of Ireland. A pseudonym is used here to protect her identity.

23. Department of Health A 121/0 "Evacuees on Home Assistance" File, National Archives of Ireland.

24. Joseph Carroll, Luck of the Irish: Poignant Saga of an Irish Family Arriving in England Just at the Outbreak of World War II (Bloomington, IN: Xlibris Corporation, 2012), 107.

25. Pauline is described as the child of the late Francis Donovan, "member of an esteemed London-Irish family," Irish Independent, January 22, 1940, 5.

26. Joan O'Neill, Daisy Chain War (Dublin: Attic Press, 1990); Webster, "Enemies, Allies," 65; Wendy Ugolini, Experiencing War as the "Enemy Other": Italian Scottish Experience in World War II (Manchester: Manchester University Press, 2011).

27. Welshman, Churchill's Children, 11 .

28. Welshman, Churchill's Children, 11. 